J. Perinat. Med. 14 (1986) 251

\title{
Total nitrogen and electrolyte levels in colostrum and transition human milk
}

\author{
Maria L. S. Ferlin, José R. Santoro, Salim M. Jorge, and Arthur L. Gonçalves
}

Departments of Gynecology, Obstetrics and Pediatrics, Faculty of Medicine of Ribeirão Preto, University of São Paulo, Brazil

\section{Introduction}

The composition of human milk has been studied extensively, but the results obtained thus far can only be considered preliminary. Numerous controversial aspects exist. There is general agreement on the variability in chemical composition of maternal milk. Several decades ago, Nims et al [22] considered the possibility of numerous factors being involved in this variability including nutrition, sleep, activity, exercise and emotional state. Some of these factors can be conditioned by the maternal socioeconomic level. WALKER et al [29] and HYTTEN and THOMPSON (1960, quoted by BAILEY [2]) believe that nutritional status and race do not affect milk composition significantly. CARNEIRO and DUtRa DE Oliveira [5], in a study carried out in Ribeirão Preto, Brazil, detected no important variation in total protein and fat content between the milk of mothers of high socioeconomic level and mothers of low socioeconomic level. Similar results were noted for calcium and phosphate content, although the levels of these electrolytes were a little higher and a little lower, respectively, than those reported in the literature. The time of gestation is another much debated and controversial point. Some investigators found that the milk of mothers who delivered prematurely was richer in protein, sodium and chloride than of mothers who

\section{Curriculum vitae}

Maria Lucia Silveira FERLIN was born in 1946 in Ribeirão Preto, state of São Paulo, Brazil. She was graduated from the Faculty of Medicine of Ribeirão Preto, University of São Paulo in Biological Sciences, 1969 and Medicine 1973. Post graduate Pediatric training in Department of Gynecology, Obstetrics and Pediatrics of the Hospital das Clinicas da Faculdade de Medicina de Ribeirão Preto in 1974 and 1975. She received a Master Degree in 1981, and was appointed an Assistant Professor. Her field of interest: Neonatology.

delivered at term $[9,10]$, although no variation was detected in potassium, calcium, phosphate and magnesium levels. MACY [20], LONNERDAL et al [17], Hambraeus et al [12] and SCHANLER and $\mathrm{OH}$ [27] observed a tendency towards higher protein concentration, the closer to delivery the milk was obtained. To determine the nutritional value of human milk, laboratory analysis is absolutely necessary. The physical and environmental conditions of the nursing mother should also be known and controlled especially in terms of the present and past nutritional status, particularly during the critical growth 
periods in human life represented by early infancy and puberty. The objective of the present research was to study the levels of sodium, chloride, potassium, calcium, phosphate and magnesium at $48,72,96,120$ and 144 hours after delivery ( \pm 9 hours), as well as protein content (144 \pm 9 hours after delivery) in the milk secretion of both mothers who had delivered at term and prematurely. The study was limited to the time of hospitalization in order to establish a few parameters such as type of delivery, physical activity, nutrition and stimulation by nursing.

\section{i Material and methods}

The study was carried out on 24 parturients hospitalized in the Obstetrics Ward of the University Hospital, Medical School of Ribeirão Preto, University of São Paulo, during the period from August 25, 1978 to May 22, 1980. All mothers had normal deliveries. They were interviewed and gave informed consent to participate in the study. The mothers were divided into two groups:

Group I, mothers who had delivered at term after 38-42 week gestation and whose babies weighed $2,500-4,00 \mathrm{~g}$ and measured 46 to $52 \mathrm{~cm}$ in length.

Group II, mothers who had delivered prematurely after gestation of less than 36 weeks, and whose babies weighed less than $2,500 \mathrm{~g}$ and measured less than $46 \mathrm{~cm}$ in length.

The two groups conformed with the guidelines of Dubowitz et al [6] and REZENDE et al [25].

Collection of colostrum and transition milk: All mothers were allowed to begin nursing 12 hours after delivery and the babies were allowed to nurse for 15 minutes from each breast with a short interval between breasts. The first breast was always alternated. In view of their weak sucking ability during the first days of life, the preterm babies were replaced with other children from the hospital nursery after all mothers involved had given their consent, so that the sucking stimulus could be maintained in a efficient way.
Colostrum and transition milk samples were collected daily at $9: 00 \mathrm{a} . \mathrm{m}$. starting $48 \pm 9$ hours after delivery, and then $72 \pm 9$ hours, $96 \pm 9$ hours, $120 \pm 9$ hours and $144 \pm 9$ hours after delivery. The intervals were intentionally kept short so that variations in content due to the natural and relatively rapid changes occurring in milk secretion from colostrum to transition milk and mature milk could be detected up to the 14th day after delivery. The samples were collected as follows. The newborn was allowed to nurse for 3 minutes and the feeding was interrupted and a mechanical breast pump was applied to the breast for 3 minutes after which the newborn was allowed to resume nursing $[11,14,15,19,22]$. The mechanical milking was carried out at random on the left or right breast since no variation in milk composition occurs between breasts [4]. The milk secretion thus obtained was stored frozen at $-20^{\circ} \mathrm{C}$.

Electrolyte measurement: Sodium and potassium were measured with an Evans Electroselenium Limited flame photometer; chloride was measured with a Corning $920 \mathrm{M}$ chloride meter. Magnesium and calcium were determined with a Perkin Elmer 290 B atom absorption spectrophotometer. Phosphate was measured by the method of RICHTERICH [26] using milk samples that had been incinerated for 12 hours at $600^{\circ} \mathrm{C}$. Nitrogen was measured by the method of Kjeldahl [21].

Statistical analysis: Median, 25th and 75th percentiles of the electrolytes studied and of protein were calculated for each time point for both groups and compared within each group for the different times and between groups for the corresponding times. The data were analyzed by nonparametric methods, using the median test for 2 independent samples and the Friedman test for dependent samples [28]. The level of significance was established at $\alpha=5 \%$.

\section{Results}

Sodium, chloride, magnesium, potassium, calcium, phosphate and nitrogen values (median, 25 th and 75th percentiles) are shown in table 


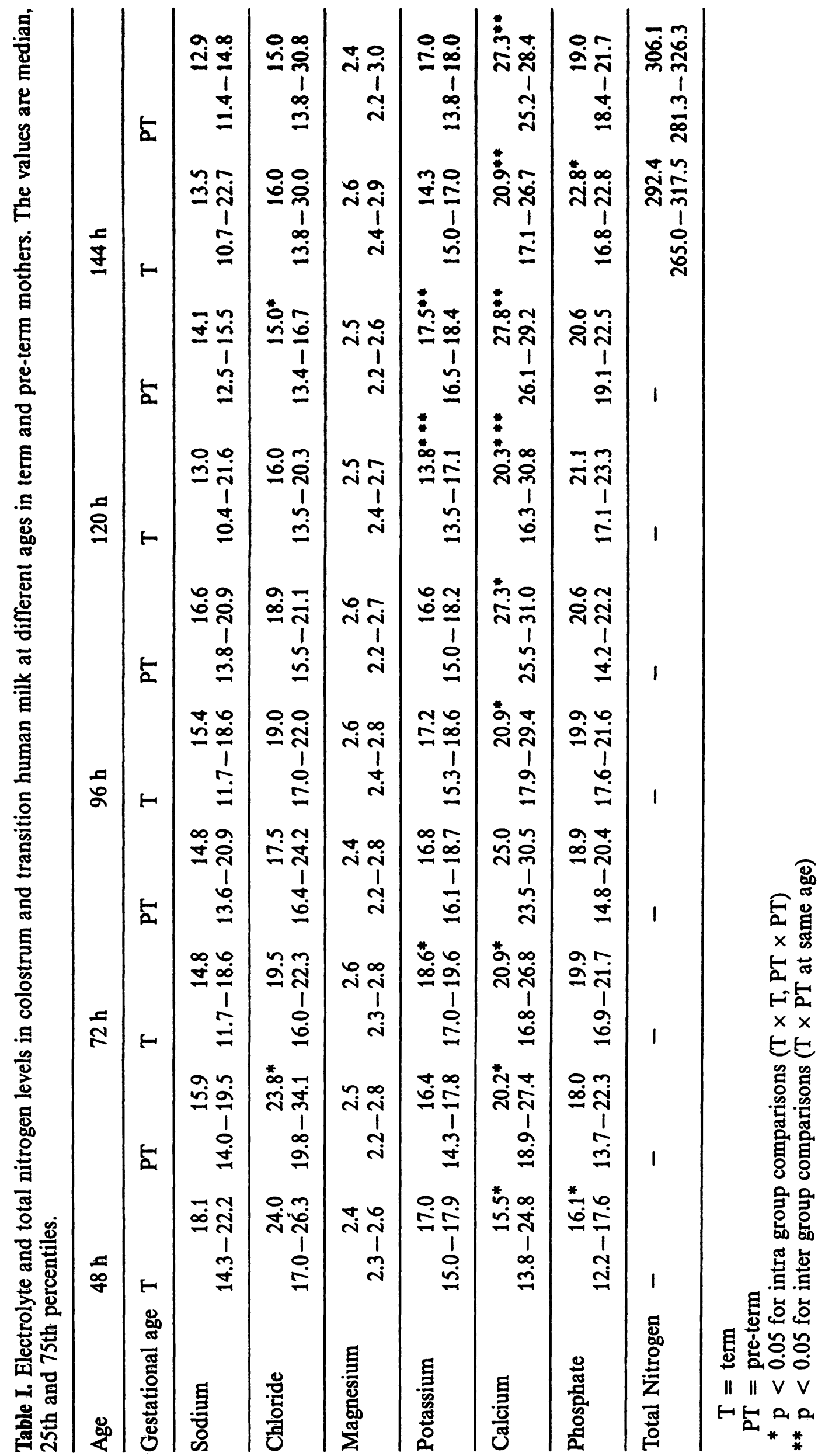


I. Potassium levels were significantly higher 72 hours after delivery among the mothers who had delivered at term, in comparison with the levels detected at 120 and 144 hours. Calcium showed the lowest levels 48 hours after delivery in both groups and these values were significantly different from other ages. Phosphate was lowest 48 hours after delivery in term mothers, increasing afterwards, with significant difference at 144 hours; but in preterm mothers no statistical difference was seen. Cloride levels were highest at 48 hours in both groups, falling in the other ages, with statistical significant difference only between 48 and 120 hours in the preterm mothers. Intergroup comparisons showed slight but significant difference between term and preterm mothers only for potassium at 120 hours and calcium at 120 and 144 hours. The remaining electrolyte and nitrogen levels showed no intragroup differences at the time points studied.

\section{Discussion}

The objective of the present paper was to compare the milk composition of mothers who delivered at term and prematurely. The latter are in a very special position, since they deliver before completion of the gestational cycle and must nurse babies with low birth weights due to the prematurity, but able to grow at a faster rate than term babies, as is the case during the final trimester of gestation when the fetus doubles the weight it had reached by the end of the second trimester. This faster growth rates may require higher nutrient levels, which must be provided by the mother by milk secretion. FOMON et al [7] reached the conclusion that maternal milk may be insufficient for preterm babies. In contrast, ATKINSON et al [1] claimed that the milk of mothers who deliver premature babies is richer in protein, thus satisfying the increased nutritional needs of the baby. The literature on this subject is inconclusive.

Research should not be limited to sample measurement of nutrient levels. The personal condition of the mother should also be considered in order to better determine the effect of time of gestation and maternal nutritional status on milk composition. This however, has not been done.

In the present study, both the electropositive (sodium, potassium, calcium, magnesium) and electronegative (chloride and phosphate) electrolytes were studied. Both groups play an important role in tissue constitution and fluid composition in the organism. Since the growth rate of children, decreases with age, as is plainly seen during the first years of life, it is natural to expect that milk secretion should be richer in nutriente at first and progressively have lower electrolyte and protein concentrations as the baby's growth rate decrease. Evidence supporting this proposition has been presented by SCHANLER and $\mathrm{OH}$ [27], who, in a study of total nitrogen and sodium, potassium and calcium levels, detected a sharply decreasing curve for all of these electrolytes (except calcium) from colostrum to mature milk.

A general overview of the data obtained in the present study showed no change in the levels of the electrolytes studied from colostrum to transition milk. Some oscillations were detected in potassium, calcium, chloride and phosphate. However, even though some of these changes were significant when compared with the remaining intragroup levels, they could hardly be explained by metabolic or hormonal effects that might be occurring in the maternal organism. During gestation, for example, the adrenal cortex produces increased amounts of hormones which reach a peak during the stress of delivery and return to normal levels within the first few days after delivery $[3,8,13]$. Under these conditions, the response of the mammary gland should cause reduced sodium levels and increased potassium content (WOLFSON and HEMERLINE, 1952; quoted by GUNTHER et al [30]), with a decreased sodium/potassium ratio. This did not occur in our study. Similarly, the levels of some electrolytes were lower than those reported in the literature and closer to those reported for mature milk. A parameter that was not studied in the present investigation nor in the surveyed literature is the possible 
malnutrition suffered by the mother during the critical growth phases such as the first three years of life and puberty. This malnutrition may have an effect by altering the structural makeup of the mammary gland and its capacity for secretion. Furthermore, because the mammary gland is an excretory organ, the food ingested also has an effect on the composition of maternal milk. In this respect, hospitalized patients such as those studied in the present investigation can be better observed because they receive the same kind of food although the amount ingested may vary among patients. This may be the reason why the individual values obtained in the present study showed relatively small variations when compared to those reported in the literature. Considerable variations in milk composition are detected in mature milk, when the effect of the diet is important in addition to maternal nutritional status and physical activity. The composition of maternal milk is a subject of controversy in the literature and this may be due to its multifactorial nature. PrINSLOo et al [24] quoted studies by other investigators [16, 29] who considered maternal race and nutritional status to be parameters that do not significantly affect milk composition. BAILEY [2] detected reduced protein levels in the milk of undernourished New Guinea mothers, as well

\section{Summary}

The objective of this research was to study the composition of human milk in terms of protein levels and levels of the electrolytes sodium, potassium, calcium, magnesium, phosphorus and chloride in colostrum $48-72$ hours post-partum, and in the transition milk ( $96 \pm 9$ hours, $120 \pm 9$ hours and $144 \pm 9$ hours post-partum of mothers who had fullterm and pre-term deliveries. The mothers were kept in the hospital with the objective to control a few important lactation parameters such as exercising or resting conditions, sleep, nutrition and suckling stimulation. Only low socioeconomic level mothers took part in the study. The initial period of lactation was studied because this is the time when secretion suffers rapid changes, going from colostrum to transition milk, and then to mature milk.

The results observed for the different times and for the two groups were compared both within and between groups. No significant differences were obtained for any of the comparisons, except for transitory oscillations as low calcium, magnesium, sodium and potassium levels, and the same has been reported by Peters [23].

In the present study, protein levels did not vary in transition milk and no difference was observed between the group of mothers who had delivered at term or prematurely. This result is not in agreement with the data reported in the literature. MACY [20], CARNEIRO and DUTRA DE OlIVEIRA [5], LONNERDAL et al [17, 18], HAMBRAEUS et al [12], AtKInson et al [1], SCHANLER and $\mathrm{OH}$ [27] and Gross et al [10] detected a decreasing curve for protein from colostrum to transition milk and mature milk. At equal lactation times, the milk of mothers who delivered prematurely had higher protein levels. On the basis of the present study, we believe that these differences can only be explained by the different organic, emotional and environmental conditions of the mothers. Not only milk composition, but volume secreted and duration of lactation must be linked with the multifactorial complex that controls lactation as a whole. Therefore it is justified to include parameters such as socioeconomic level, present and previous nutritional status and emotional balance of the mother in the study of the composition of human milk.

in potassium, calcium, chloride and phosphorus levels observed within groups. In general, it can be said that there was no variation between colostrum and transition milk for the mothers who delivered at full term or preterm. No differences were found either when the groups were compared at the different times post-partum. This means that, under the conditions used in this study, milk did not vary as its type naturally changed (from colostrum to transition milk) for the two groups and that the levels of the constituents studied also remained unchanged when studied as a function of full-term or pre-term delivery. The results disagree with some of those published in the literature, probably owing to the multifactorial nature of lactation. Thus, further studies are needed, with careful control of the different factors, including previous nutritional status of the mothers, especially during the critical times of development represented by early infancy and puberty.

Keywords: Colostrum, electrolytes, human milk, pre-term, protein, term, transition milk. 
Gesamt-N- und Elektrolytspiegel im Kolostrum und in der transitorischen Milch

Inhalt unserer Studie war die Zusammensetzung der Brustmilch in Bezug auf den Proteingehalt sowie die Konzentrationen von Natrium, Kalium, Kalzium, Magnesium, Phosphat und Chlor. Bei Frauen, die am Termin entbunden worden waren und bei einer zweiten Gruppe von Frauen nach Frühgeburt wurden die Kolostralmilch $(48-72 \mathrm{~h}$ post partum) sowie die Übergangsmilch (96 $\pm 9 \mathrm{~h}, 120 \pm 9 \mathrm{~h}$ und $144 \pm 9 \mathrm{~h}$ post partum) untersucht. Um einige wichtige Parameter, wie z. B. Stillund Ruhebedingungen, Schlaf, Ernährung und Stimulation zum Saugen kontrollieren zu können, wurden die Untersuchungen bei stationär untergebrachten Frauen durchgeführt. In der Studie wurden nur Frauen aus sozial niedrig gestellten Schichten berücksichtigt. Die frühe Laktationsperiode wurde deshalb untersucht, weil die Sekretion in dieser Phase rasche Veränderungen erfährt, nämlich von Kolostrum zur Übergangsmilch und dann schließlich zur reifen Milch.

Die bei den beiden Gruppen zu den unterschiedlichen Zeitpunkten erhaltenen Werte wurden innerhalb sowie zwischen den Gruppen miteinander verglichen. Mit der
Ausnahme, daß transitorische Schwankungen in Bezug auf den Kalium-, Calcium-, Chlor- und Phosphatspiegel innerhalb der beiden Gruppen zu beobachten waren, ergab der Vergleich keine signifikanten Unterschiede. Allgemein ausgedrückt: weder bei Frauen am Termin noch bei Frauen nach Frühgeburt unterscheiden sich Kolostrum und Übergangsmilch. Auch bei Vergleich der zu den unterschiedlichen Zeitpunkten post partum erhaltenen Werte zeigten sich keine Unterschiede. Unter den in unserer Studie vorliegenden Bedingungen änderte sich die Zusammensetzung der Milch beim Übergang vom Kolostrum zur transitorischen Milch in beiden Gruppen nicht, unabhängig davon, ob sie nach termingerechter Geburt untersucht wurde oder nach Frühgeburt. Diese Ergebnisse widersprechen einigen Veröffentlichungen, wobei es $\mathrm{zu}$ berücksichtigen gilt, daß die Laktation ein multifaktorieller Prozeß ist. Daher sind weitere Untersuchungen notwendig, die die unterschiedlichen Faktoren stärker berücksichtigen wie z. B. den früheren Ernährungszustand der Mütter, speżiell während der kritischen Entwicklungsphasen in der frühen Kindheit und Pubertät.

Schlüsselwörter: Brustmilch, Elektrolyte, Frühgeburt, Geburt am Termin, Kolostrum, Protein, Übergangsmilch.

\section{Résumé}

Taux d'azote et d'électrolytes dans le colostrum et dans le lait humain de transition

L'objectif de cette recherche a été d'étudier la composition du lait humain en matière de taux de protéines et d'électrolytes, Sodium, Potassium, Calcium, Magnésium, Phosphore et Clore dans le colostrum dans les 48-72 heures du post-partum, et dans le lait de transition (96 \pm 9 heures, $120 \pm 9$ heures et $144 \pm 9$ heures du post-partum) de mères ayant accouché à terme et d'autres prématurément. Les mères restaient à l'hôpital afin de contrôler quelques paramètres importants concernant la lactation, tels que activités ou repos, sommeil, nutrition et stimulations mamelonnaires. Seules des mères de bas niveau socio-économique ont fait partie de l'étude. On a étudié la période initiale de lactation car c'est à ce moment que la secretion subit des modifications rapides, allant du colostrum au lait de transition, puis au lait mature.

On a comparé les résultats observés dans les deux groupes aux différentes périodes au sein de chaque groupe et d'un groupe à l'autre. Il n'a pas été obtenu de différences significatives pour chaque comparaison à l'exception de variations transitoires observées à l'intérieur des groupes pour les taux de Potassium, de Calcium, de Chlore et de Phosphore. On peut dire qu'en règle générale, il n'y a pas de variation entre le colostrum et le lait de transition que les mères aient accouché à terme ou prématurément. De même on n'a pas trouvé dè différence en comparant les groupes aux différents moments du post-partum. Celà signifie que, dans les conditions de notre étude, le lait n'est pas différent d'un groupe à l'autre même si son type se modifie naturellement (du colostrum au lait de transition) et que les taux des constituants étudiés demeurent également inchangés lorsqu'on les étudie en fonction de l'accouchement à terme ou prématuré. Ces résultats ne sont pas en accord avec d'autres publiés dans la littérature, celà est probablement dû à la nature multifactorielle de la lactation. Ainsi, d'autres études sont nécessaires, avec un contrôle soigneux des différents facteurs, y compris le status nutritionnel antérieur de la mère, tout spécialement au cours de la période critique de développement représentée par la petite enfance et la puberté.

Mots-clés: Colostrum, électrolytes, lait de transition, lait humain, pré-terme, protéïne, terme. 


\section{References}

[1] AtKinson SA, MH BRyAN, GH ANDERSON: Human milk; Difference in nitrogen concentration in milk from mothers of term and premature infants. $J$ Pediatr 93 (1978) 67

[2] BAILEY KV: Quantity and composition of breast milk in some New Guinean populations. J Trop Pediatr 11 (1965) 35

[3] BAYIISS RIS, JC MAC BROWNE, BP ROUND, RAW STEINBECK: Plasma 17 hydroxycorticosteroids in pregnancy. Lancet I (1955) 62

[4] BROWN M, IG MACY, B Nims, HA HUNSCHBR: Human milk studics VIII. A comparison of the composition of the milk from the two breasts. Am J Dis Child 43 (1932) 40

[5] Carneiro TA, JE Dutra de Oliveira: Nutritional studies in human lactation in Brazil. 1. Chemical composition of breast milk. J Trop Pediatr 19 (1973) 384

[6] Dubowitz LMS, V Dubowitz, C Goldberg: Clinical assessment of gestational age in the newborn infant. J Pediatr 77 (1970) 1

[7] FOMON SJ, EE ZILGLIR, HD VĀSQUEZ: Human milk and the small premature infant. Am J Dis Child 131 (1977) 463

[8] Gemzill CA: Blood levels of 17-hydroxycorticosteroids in normal pregnancy. J Clin Endocrinol Metab 13 (1953) 898

[9] Gross SJ, RJ DAvid, L Bauman, RM Tomarelli: Nutritional composition of human milk in mothers of pr-term infants. Pediatr Res 13 (1979) 400

[10] Gross SJ, RJ DAvid, L Bauman, RM TOMAREILl: Nutritional composition of milk produced by mothers delivering pre-term. J Pediatr 96 (1980) 641

[11] Gunther M, DF Hawkins, GA Whyley: Somc observations on the sodium and potassium content of human milk. J Obstet Gynaecol Br Cwth 72 (1965) 69

[12] Hambraeus L, B Lonnerdal, E Forsum, M GebreMEDIIN: Nitrogen and protein components of human milk. Acta Paediatr Scand 67 (1978) 561

[13] HAWKINS DF, WCW Nixon: Blood electrolytes in prolonged labour. J Obstet Gynaecol Br Emp 64 (1957) 641

[14] HYTTEN FE: Clinical and chemical studies in human lactation. II. Variation in major constituents during a feeding. Br Med J 1 (1954) 176

[15] HYTTEN FE: Clinical and chemical studies in human lactation. III. Diurnal variation in major constituents of milk. Br Med J 1 (1964) 179

[16] HYTTEN FE, AM THOMPSON: In milk: the mammary gland and its secretion. Vol. II. Academic Press, London 1960. ap. BAILEY KV: Quantity and composition of breast milk in some New Guincan populations. J Trop Pediatr 11 (1965) 35

[17] LONNerdal B, E Forsum, L HambraeUs: A longitudinal study of the protein, nitrogen and lactose contents of human milk from Swedish well-nourished mothers. Am J Clin Nutr 29 (1976) 1127

[18] Lonnerdal B, E Forsum, M Gibre-Mizdinn, L Hambrarus: Breast milk composition in Ethiopian and Swedist mothers. II. Lactose, nitrogen and protein contents. Am J Clin Nutr 29 (1976) 1134

[19] Macy G, B Nims, M Brown, HA HunschirR: Human milk studies. VII. Chemical analysis of milk representative of the entire first and last halves of the nursing period. Am J Dis Child 42 (1931) 569

[20] MACY IG: Composition of human colostrum and milk. Am J Dis Child 78 (1949) 589

[21] Natzlson S: Nitrōgeno total. In Microtēenicas de Quīmica Clīnica. 2a. ediciōn. Ediciones Toray, Barcelona 1964

[22] Nims B, IG MACY, M Brown, HA Hunschib: Human milk studies. IX. Variations in the composition of milk at four hour intervals during the day and night. Am J Dis Child 43 (1932) 828

[23] Peters FE: The chemical composition of New Hebridean human milk. Br J Nutr 7 (1953) 208

[24] Prinsloo JG, W Wittmann, ESP S'rrydom, DB Villiers, as Wehmeyizr, NF Laubscher, MA Botha: Composition of breast milk from Bantu and white woman of the fifth post partum day. S Afr Med J 44 (1970) 738

[25] REZENDE J, JC NAHOUM, JM BARCiLlos: A interrupção prematura espontãnca da prenhez. In: RizENDE J: Obstetrīia, 3". ed. Guanabara - Koogan, Rio de Janeiro 1974

[26] Richterich R: Anorganischer Phosphor: Mobydänblau-Methode. In: Klinische Chemie-Theorie und Praxis. S. Karger, Basel-New York 1965

[27] SCHANLeR RJ, W OH: Composition of breast milk obtained from mothers of premature infants as compared to breast milk oblained from donors. J Pediatr 96 (1980) 679

[28] Sirgel S: Nonparametric statistics for the behavioral sciences. International student edition. McGrawHill-Kogokusha Ltd., London 1956

[29] Walker ARP, UB ARvidsson, WL Draper: The composition of breast milk of South African Bantu mothers. Trans R Soc Trop Med Hyg 48 (1954) 395

[30] Wolfson NW, AE Hemrri.INe: Unic Mich Med Bull 18 (1952) 301. ap. GunrHer M, DF HAWKINS, GA WuYLEY: Some observations on the sodium and potassium content of human milk. J Obstct Gynaccol Br Cwth 72 (1965) 69

Reccived March 18, 1985. Revised August 8, 1985. Accepted September 4, 1985.

Maria Lūcia Silveira Forlin Hospital das Clīnicas - Sctor de Pcdiatria Campus Universitārio Ribeirão Preto 14.100 - Ribeirão Preto, SP, Brasil 


\section{Fertility and Antifertility Aspects}

\section{Editor M. Schmidt-Gollwitzer}

Co-editor R. Schley

1985. $17 \times 24 \mathrm{~cm}$. X, 357 pages. With 174 illustrations and 54 tables.

Paper. DM 98,-

ISBN $311010055 X$

(New Developments in Biosciences 1)

The newly established series 'New Developments in Biosciences' publishes at regular intervals current results from medical and biological basic fundamental research.

This volume deals with 'conception and contraception' on the basis of the latest findings in the field of gynecological endocrinology. The hormonal regulation of the ovarian cycle as a basis for contraceptional intervention opens up such a broad field for special research that it seemed appropriate to publish the results obtained so far as a separate volume in this series.

Internationally renowned scholars give a state-of-the-art report, which enables both colleagues and basic fundamental researchers to obtain exact and complete information about the present standard of knowledge.

Forthcoming titles in the series will provide interdisciplinary information on a particular branch of natural science in an easy-accessible and comprehensive form.
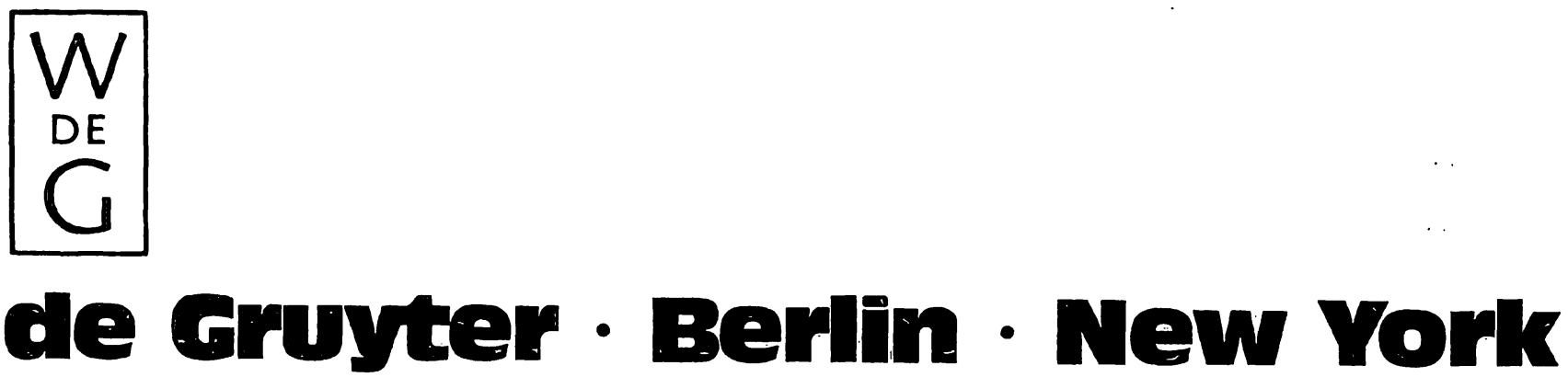